\title{
Analysis of a chosen combustion parameters of dual fuel SI engine fuelled with alcohol and gasoline
}

\begin{abstract}
The paper presents comparison of a selected combustion parameters of dual fuel, spark ignited engine run on gasoline and methyl alcohol. To the testing was used a four cylinder Fiat 1100 MPI engine with multipoint injection of gasoline and alcohol to area of inlet valve. Preliminary tests of the engine pointed at significant differences of its performance when the engine was run on alcohol only and on gasoline only [1]. In connection with it an indicator tests were performed in order to determine, on their base, a differences present in runs of combustions of the both fuels. The paper presents comparison of maximal pressure, rate of pressure rise, average temperature of working medium, heat release rate, total angle of combustion and indicated efficiency. These parameters were analyzed both in function of crankshaft rotation angle as well as engine load. Obtained results show at different course of methanol combustion comparing to gasoline. Run of methanol combustion is more rapid, what leads to growth of engine efficiency and increase of maximal cylinder pressures. Growth of working medium temperatures during combustion, what can lead to growth of thermal load of the engine, can be included to disadvantageous phenomena. Performed tests point at necessity of engine tuning modification during feeding with methanol, what would enable to take full benefits of advantageous properties of that fuel. Simultaneously, optimization tests have enabled to restrict disadvantageous effects of combustion of methanol.
\end{abstract}

Key words: dual fuel engine, alcohol, exhaust gas toxicity, indicated efficiency, engine load

\section{Analiza wybranych parametrów spalania dwupaliwowego silnika o zapłonie iskrowym zasilanego alkoholem i benzyną}

\begin{abstract}
W artykule przedstawiono porównanie wybranych parametrów spalania dwupaliwowego silnika o zapłonie iskrowym zasilanego alkoholem metylowym oraz benzyna. Do badań wykorzystano 4-cylindrowy silnik Fiat 1100 MPI z wielopunktowym wtryskiem alkoholu i benzyny w okolice zaworu dolotowego. Badania wstepne silnika wykazaty istotne różnice jego parametrów zewnętrznych przy zasilaniu samym alkoholem i sama benzyna [1]. W zwiazku z tym przeprowadzono badania indykatorowe, aby na ich podstawie określić różnice występujące w przebiegu spalania obydwu paliw. W artykule przedstawiono porównanie ciśnienia maksymalnego, szybkości narastania ciśnienia, średniej temperatury czynnika, szybkości wydzielania ciepla, całkowitego kata spalania oraz sprawności indykowanej. Parametry te analizowano zarówno w funkcji kąta obrotu wału korbowego, jak i obciązenia silnika. Otrzymane wyniki wskazują na odmienny przebieg spalania metanolu w stosunku do benzyny. Przebieg spalania metanolu jest szybszy, co prowadzi do wzrostu sprawności silnika oraz podwyższenia maksymalnych ciśnień w cylindrze. Do niekorzystnych zjawisk należy zaliczyć wzrost temperatur czynnika podczas spalania, co może prowadzić do wzrostu obciązenia cieplnego silnika. Przeprowadzone badania wskazują na konieczność zmian regulacji silnika przy zasilaniu metanolem, które pozwolityby w petni wykorzystać korzystne właściwości tego paliwa. Równocześnie badania optymalizacyjne pozwolityby ograniczyć niekorzystne skutki spalania metanolu.
\end{abstract}

Słowa kluczowe: silnik dwupaliwowy, alkohol, składniki toksyczne spalin, sprawność indykowana, obciążenie silnika

\section{Introduction}

The nineties of $20^{\text {th }}$ century and beginning of the $21^{\text {st }}$ century denote the years when tendency to intensive exploration of alternative fuels for motorization can be observed. Actually, many worldwide research centers focus themselves on question which fuels are able to fully or at least partially replace traditional fuels from petroleum chemistry. Such factors as environment protection, need to maintain up-to-now engine parameters, economy of fuel production and costs connected with engine adaptation are taken into consideration in such survey. Numerous development work published recently show at renewed interest in alcohols, which belong to the fuels having significant quantities of oxygen in their chemical constitution.

\section{Wstęp}

Lata 90. XX wieku oraz początek XXI wieku to okres, w którym można zaobserwować tendencje do intensywnych poszukiwań alternatywnych paliw dla motoryzacji. Wiele ośrodków badawczych na całym świecie skupia się nad tym, jakie paliwa są w stanie całkowicie lub choćby częściowo zastąpić tradycyjne paliwa ropopochodne. Bierze się przy tym pod uwagę takie czynniki, jak: ochrona środowiska, utrzymanie dotychczasowych parametrów silnikowych, ekonomia wytwarzania paliwa oraz koszty związane $\mathrm{z}$ adaptacją silnika. Liczne prace badawcze ukazujące się w ostatnim okresie wskazują, że ponownie zaczęto się interesować alkoholami, będącymi paliwami, które w swym składzie zwierają znaczne ilości tlenu. 
Alcohols, as a self-contained engine fuels were already used as early as by the end of 19th century, and next were added as component to fuels by air force during period of the First and the Second World War [2, 3, 4]. Additive of alcohol, in prevailing majority ethanol, increased octane number of the fuel, what prevented knocking combustion $[3,5]$. During between war period and after the Second World War were also developed engines run on alcohol only. In the fifties of the previous century one gradually reduced usage of the alcohols, replacing them with fuels extracted from crude oil, which today practically predominate fuelling of piston engines. Renewed interest in alcohols has been observed in the seventies, what was caused by crude oil's price growth and restrictions in usage of lead compounds to gasoline. Alcohols, as additives to fuel had as their task to increase octane number of gasoline. The main problem of gasoline-alcohol mixtures these times was stratification of the mixtures, what during the next years was eliminated by usage of stabilizers, mainly esters like methyl-tert-butyl-ester. Addition of stabilizers enabled to increase fraction of alcohol from a few to over a dozen percent by volume. From ,engine operation" point of view, anyhow, much more advantageous is usage of alcohol as a self-contained fuel, because it allows to take full advantage of high knocking resistance of the alcohol, enabling increase of compression ratio, growth of overall efficiency and unit output power of the engine $[3,4$, 6]. Such feeding system is especially developed in Brazil, nevertheless is also used in other countries like USA and New Zealand among others [2, 7].

Elimination of alcohol's drawback connected with stratification of its mixtures with gasoline or diesel oil, technological progress connected with engine feeding and control systems which occurred recently, advantages connected with significantly lower toxicity of exhaust gases, higher octane number and possibility of improvement of engine parameters cause that the alcohols (methanol and ethanol) become objects of interest for much bigger scale than in the past. It can be proved by numerous papers published in the recent years because test results presented in these papers are promising [13, 15-20, 22, 23, 25-27].

In course of the tests a big attention was devoted to analysis of combustion of fuel which comprised alcohol, and its effect on engine parameters. Results of the tests reported in the publications $[14,16,21,22,24,25]$ show that during the combustion, additive of alcohols contributed to growth of temperature of working medium and growth of heat release rate in the cylinder. In self-ignition engines it was found a bigger delay of the self-ignition, however combustion was more rapid, and total time of combustion of alcohol mixtures was shorter comparing to diesel oil. Proper selection of ignition advance angle in case SI engines is important, because higher temperatures and pressures accompanying combustion of alcohol could create a cause of damaged pistons, cylinders or valves [21].

Spark ignition engines can be fuelled through injection of the mixture to inlet manifold or directly to cylinder, or in dual fuel system - through separate injection of alcohol
Alkohole jako samoistne paliwa silnikowe stosowane były już pod koniec XIX w., potem były składnikiem paliw w lotnictwie wojskowym podczas I i II wojny światowej [2, $3,4]$. Dodatek alkoholu, w przeważającej większości etylowego, zwiększał liczbę oktanową paliwa, co przeciwdziałało spalaniu stukowemu [3, 5]. W okresie międzywojennym i po II wojnie światowej powstawały również konstrukcje silników zasilanych samymi alkoholami. W latach 50. ubiegłego wieku stopniowo zmniejszano zastosowania alkoholi, zastępując je paliwami ropopochodnymi, które obecnie dominują w zasilaniu silników tłokowych. Ponowne zainteresowanie alkoholami obserwowano w latach siedemdziesiątych XX w., co było spowodowane wzrostem cen ropy naftowej i ograniczeniem związków ołowiu w benzynach. Alkohole jako dodatki paliw miały za zadanie zwiększyć liczbę oktanową benzyn. Głównym problem mieszanin benzyna-alkohol było wtedy zjawisko rozwarstwiania się mieszanin, co w latach późniejszych wyeliminowano przez zastosowanie stabilizatorów, głównie eterów, na przykład metylo-tert-butylowego. Dodatek stabilizatorów pozwalał na powiększenie udziału alkoholu z kilku do kilkunastu procent objętościowych. Z punktu widzenia zastosowań silnikowych znacznie korzystniejsze jest jednak stosowanie alkoholu jako paliwa samoistnego, bowiem pozwala to $\mathrm{w}$ pełni wykorzystać dużą odporność przeciwstukową alkoholu, umożliwiającą zwiększenie stopnia sprężania, wzrost sprawności ogólnej i mocy jednostkowej silnika $[3,4,6]$. Ten system zasilania jest szczególnie rozwinięty w Brazylii, ale stosuje się go również w innych krajach, między innymi w USA oraz Nowej Zelandii [2, 7].

Wyeliminowanie zjawiska rozwarstwiania się mieszanin alkoholi z benzyną lub olejem napędowym, postęp techniczny, jaki miał miejsce w ostatnim czasie w układach zasilania oraz w układach sterowania silnika, zalety związane ze znacznie mniejszą toksycznością spalin, z wyższą liczbą oktanową oraz z możliwością poprawiania parametrów silnika sprawiają, że alkoholami (metanolem i etanolem) zaczęto interesować się obecnie na większą skalę niż w przeszłości. Dowodem na to są liczne prace, które ukazały się w ostatnich latach, a prezentowane w nich wyniki badań są obiecujące $[13,15-20,22,23$, 25-27].

W badaniach dużo uwagi poświęcono analizie spalania paliwa zawierającego alkohol i jego wpływu na parametry silników. Wyniki badań zawarte w opracowaniach [14, 16, 21, 22, 24, 25] wskazują, że podczas spalania dodatek alkoholu przyczynia się do wzrostu temperatury czynnika oraz zwiększenia szybkości wydzielania ciepła w cylindrze. W silnikach o zapłonie samoczynnym stwierdzono wprawdzie większe opóźnienie samozapłonu, jednak spalanie przebiegało szybciej, a całkowity czas spalania mieszanin alkoholowych był krótszy w stosunku do spalania oleju napędowego. W silnikach o zapłonie iskrowym ważny jest prawidłowy dobór kąta wyprzedzenia zapłonu, bowiem towarzyszące spalaniu alkoholu wyższe temperatury i ciśnienia mogą być przyczyną uszkodzeń tłoków, cylindrów lub zaworów [21]. 
and separate injection of gasoline. Because alcohols do not form a stable mixture with gasoline (necessity of usage of stabilizers, emulsifiers or solvents), dual fuel system can became more practical.

In design solution described in the present paper, to injection of alcohol were used additional injectors in each cylinder, original injectors were destined to injection of alcohol, whereas additional ones to injection of gasoline. Such system enables simultaneous feeding of the engine with gasoline and alcohol, whereas alcohol fraction can change in the limits of $0-100 \%$, depending on engine load and rotational speed. Assumption to planned research is such that at low engine loads the engine is fuelled with gasoline only, or with mixture having small additive of alcohol. Portion of alcohol shall increase as the engine load increases. Correct composition of combusted mixture is controlled by opening time of gasoline and alcohol injectors. It should be underlined that such trend of fuelling is actually investigated by Volvo and Ford, what can be proved by information found in the literature [11].

\section{Research stand}

The tests were performed on four cylinder, spark ignited Fiat 1100 engine with multipoint injection system. Technical data of the engine are specified in the Table 1 below.

Table 1. The technical data of Fiat 1100 MPI

Tabela 1. Dane techniczne silnika Fiat 1100 MPI

\begin{tabular}{|l|c|}
\hline Engine type/typ silnika & Fiat $1100 \mathrm{MPI}$ \\
\hline Bore $\times$ stroke/średnica $\times$ skok & $70 \times 72 \mathrm{~mm}$ \\
\hline Swept capacity/pojemność silnika & $1108 \mathrm{~cm}^{3}$ \\
\hline Compression ratio/stopień sprężania & 9.6 \\
\hline $\begin{array}{l}\text { Rated power/rotational speed/moc silnika/ } \\
\text { prędkość obrotowa }\end{array}$ & $40 \mathrm{~kW} / 5000 \mathrm{rpm}$ \\
\hline $\begin{array}{l}\text { Maximal torque/rotational speed/maksymalny } \\
\text { moment obrotowy/prędkość obrotowa }\end{array}$ & $88 \mathrm{~N} \cdot \mathrm{m} / 3000 \mathrm{rpm}$ \\
\hline
\end{tabular}

Scheme of the prototype inlet manifold is illustrated in the Fig. 1, view of the engine is shown in the Fig. 2.

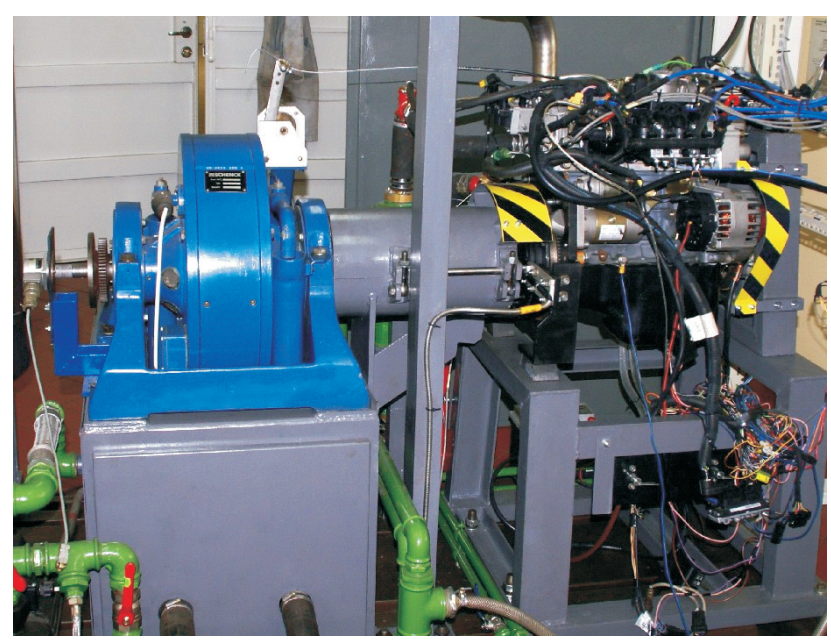

Fig. 2. View of the engine mounted on the test bed Rys. 2. Silnik na stanowisku badawczym
Silniki o zapłonie iskrowym można zasilać przez wtrysk mieszanki do kolektora dolotowego lub bezpośrednio do cylindra oraz dwupaliwowo - przez osobny wtrysk alkoholu i osobny benzyny. Ponieważ alkohole nie tworzą stabilnej mieszanki z benzyną (konieczność stosowania stabilizatorów, emulgatorów lub rozpuszczalników), praktyczniejszy może stać się układ dwupaliwowy.

$\mathrm{W}$ rozwiązaniu opisywanym w niniejszym artykule do wtrysku alkoholu zastosowano dodatkowe wtryskiwacze na każdym cylindrze, przy czym oryginalne wtryskiwacze przeznaczono do wtrysku alkoholu, natomiast dodatkowe do wtrysku benzyny. System ten umożliwia równoczesne zasilanie silnika benzyną i alkoholem, a udział alkoholu może zmieniać się w granicach 0-100\% zależnie od obciążenia i prędkości obrotowej silnika. Założeniem planowanych prac badawczych jest zasilanie silnika przy małych obciążeniach samą benzyną lub mieszaniną z niewielkim dodatkiem alkoholu. Jego udział będzie się zwiększał w miarę wzrostu obciążenia silnika. Właściwy skład spalanej mieszaniny palnej jest sterowany czasem otwarcia wtryskiwaczy benzynowego i alkoholowego. Należy zaznaczyć, że ten kierunek zasilania jest obecnie badany przez firmy Volvo i Ford, o czym świadczą doniesienia literaturowe [11].

\section{Stanowisko badawcze}

Badania przeprowadzono na 4-cylindrowym silniku o zapłonie iskrowym Fiat 1100 MPI z wielopunktowym wtryskiem paliwa. Dane techniczne silnika zamieszczono $\mathrm{w}$ tab. 1. Schemat prototypowego kolektora dolotowego przedstawiono na rys. 1, a silnik na rys. 2 .

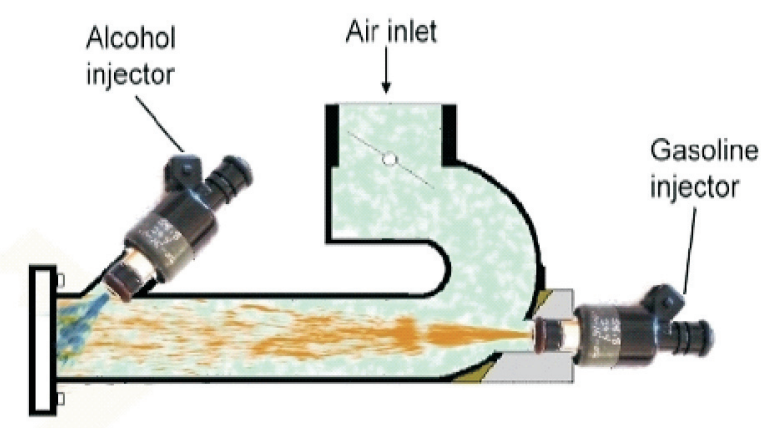

Fig. 1. Scheme of the prototype inlet manifold to Fiat 1100 MPI engine Rys. 1. Schemat prototypowego kolektora dolotowego silnika Fiat $1100 \mathrm{MPI}$

Szczegółowy opis zmian dokonanych w silniku zawarto w pracy [1]. Schemat stanowiska pomiarowego przedstawiono na rys. 3 .

\section{Omówienie wyników badań}

Badania przeprowadzono dla różnych prędkości obrotowych i zmiennych obciążeń silnika od minimalnego do maksymalnego. W czasie badań rejestrowano wykresy indykatorowe z piezokwarcowego czujnika umieszczonego $\mathrm{w}$ komorze spalania drugiego cylindra. Były one wykorzystywane do obliczeń parametrów spalania przy użyciu autorskiego programu opracowanego w Katedrze Silników 
Detailed description of the changes incorporated to the engine is presented in the work [1]. Scheme of the measuring bench is shown in the Fig. 3 .

\section{Experimental results and discussion}

The tests were performed for a various engine speeds and engine loads changing from minimal to maximal ones. In course of the testing were recorded indicator diagrams from piezoquartz detector positioned in combustion chamber of the second cylinder. The diagrams were used in calculations of combustion parameters with use of own software developed in the Internal Combustion Engines Faculty, Technical University B-B [8]. To the calculations was used an indicator diagram averaged from hundred successive cycles of individual combustions. System of data acquisition and course of performed measurements were the same, both in case of gasoline fuelling and methanol fuelling. Obtained in such way results were compared to each other. Observed differences are shown in the diagrams below.

\section{Cylinder pressure}

In the Figure 4 is shown a comparison of cylinder pressure during combustion for two selected engine speeds and various engine loads. From the comparison is seen that during combustion of alcohol are present significantly higher pressures in the cylinder, and the process of pressure growth is more rapid and more violent. Such tendency can be noticed for all engine loads and for all engine speeds. It was also found, that for medium and the highest engine loads, maximal pressures occur earlier during combustion of methanol comparing with gasoline, and in such way the maximal pressures approach to the TDC. It is one from reasons of increased unit power of the engine and its efficiency [1,8]. Different tendency was observed for the lowest loads (green colour), where in case of methanol, maximal pressures were developed later comparing to gasoline.

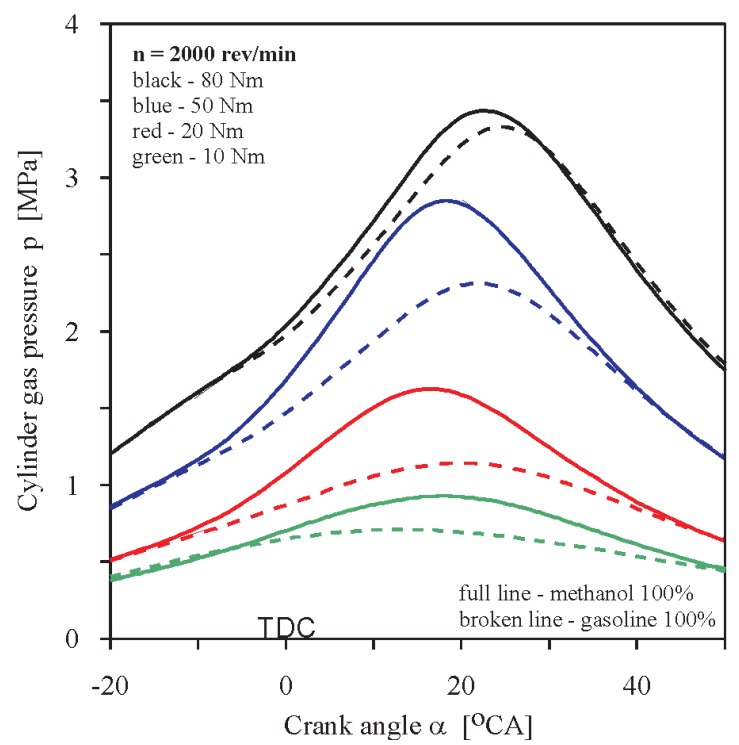

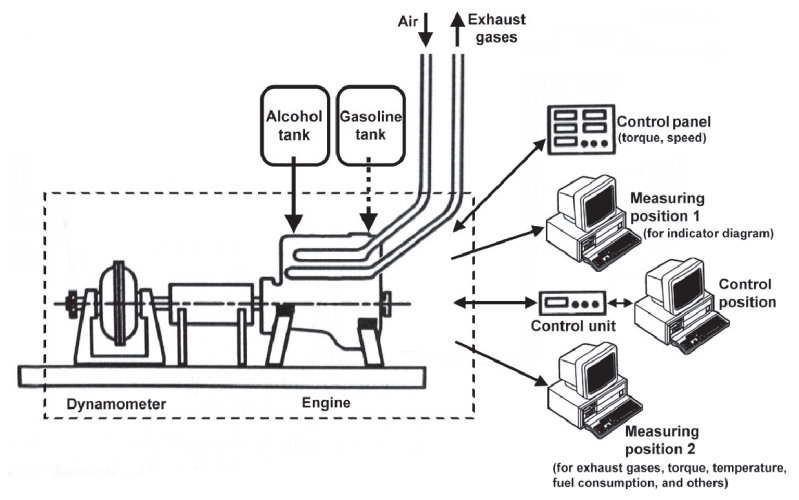

Fig. 3. Schematic diagram of the experimental set-up Rys. 3. Schemat stanowiska badawczego

Spalinowych i Pojazdów ATH w Bielsku-Białej [8]. Do obliczeń wykorzystywano uśredniony wykres indykatorowy ze stu następujących po sobie cykli pojedynczego spalania. System zbierania informacji i tok przeprowadzonych pomiarów był taki sam zarówno dla zasilania benzyną, jak i metanolem. Otrzymane w ten sposób wyniki obliczeń parametrów spalania poddano porównaniom. Zaobserwowane różnice prezentują poniższe wykresy.

\section{Ciśnienie w cylindrze}

$\mathrm{Na}$ rysunku 4 przedstawiono porównanie ciśnienia w cylindrze podczas spalania dla dwóch wybranych prędkości obrotowych i różnych obciążeń silnika. Z porównania wynika, że podczas spalania alkoholu występują znacząco większe ciśnienia w cylindrze, a sam proces zwiększania ciśnienia jest szybszy i bardziej gwałtowny. Tendencja ta zauważalna jest dla wszystkich obciążeń silnika oraz dla wszystkich prędkości obrotowych. Stwierdzono również, że dla średnich oraz najwyższych obciążeń przy spalaniu metanolu szybciej, w stosunku do benzyny, osiągane są maksymalne ciśnienia, które zbliżają się w ten sposób do GMP. Jest to jedna z przyczyn zwiększenia mocy jednost-

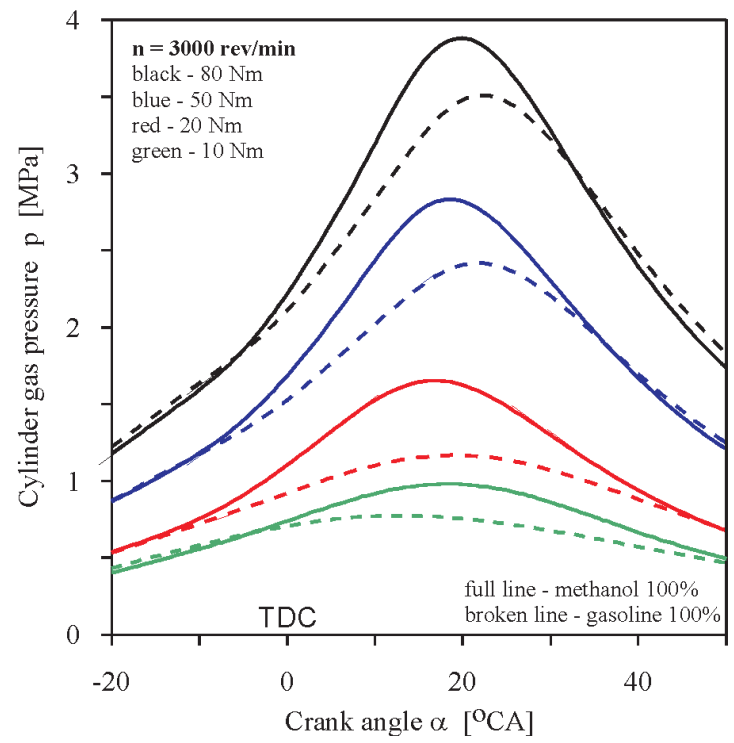

Fig. 4. Comparison of cylinder pressure in function of crank angle for a various engine loads Rys. 4. Porównanie ciśnienia w cylindrze w funkcji kąta obrotu wału korbowego dla różnych obciążén silnika 


\section{Mean temperature of the gas}

In the Figure 5 are shown differences of working medium temperature in the cylinder during combustion of gasoline and alcohol. At comparable loads, in the engine run on methanol were observed higher temperatures of the working medium, and their maximal values were developed earlier comparing to combustion of gasoline. That fact confirms higher dynamics of combustion of methanol during initial phases of the process. Higher the engine load, more smaller differences between the temperatures, anyhow during combustion of methanol is still observed a tendency to higher temperatures with respect to gasoline. It is worth to underline fact that during combustion of methanol, as early for low loads (solid line, green colour) there were observed temperatures comparable to the temperatures obtained during combustion of gasoline and high engine loads (dashed lines, blue and black colours).

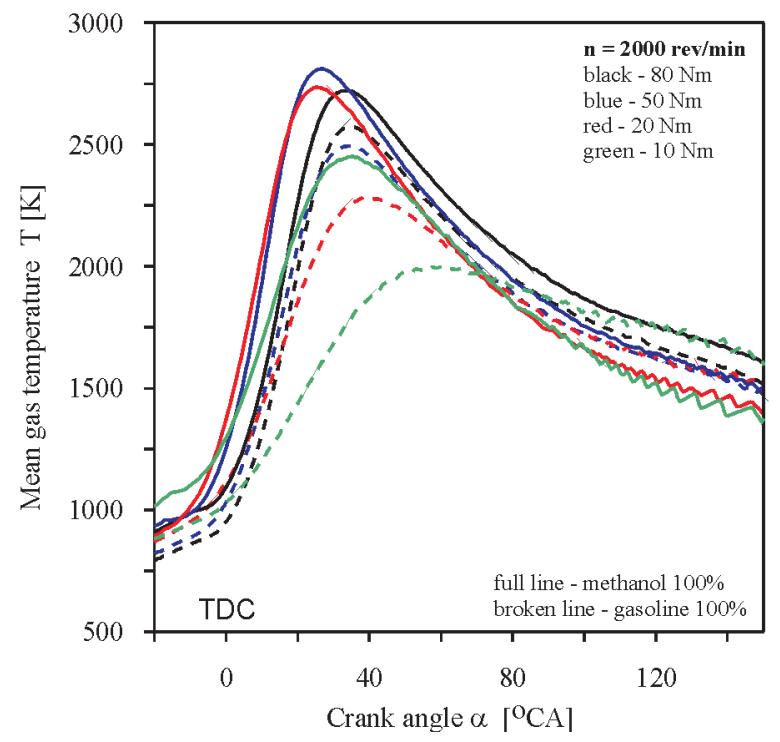

kowej silnika i jego sprawności $[1,8]$. Odmienną tendencję zauważono dla najmniejszych obciążeń (kolor zielony), gdzie w przypadku metanolu maksymalne ciśnienia były osiągane później niż dla benzyny.

\section{Średnia temperatura czynnika}

Na rysunku 5 pokazano różnice temperatur czynnika w cylindrze podczas spalania benzyny oraz alkoholu. Przy porównywalnych obciążeniach w silniku zasilanym metanolem obserwowano wyższe temperatury czynnika, a maksymalne ich wartości były osiągane wcześniej niż przy spalaniu benzyny. Fakt ten potwierdza większą dynamikę spalania metanolu w początkowych fazach procesu. Im większe obciążenie silnika, tym różnice między temperaturami zmniejszają się, jednak przy spalaniu metanolu w dalszym ciągu obserwuje się tendencję do większych temperatur w stosunku do benzyny. Warto podkreślić fakt, że przy spalaniu metanolu już dla małych obciążeń (linia ciągła, kolor zielony) obserwowano

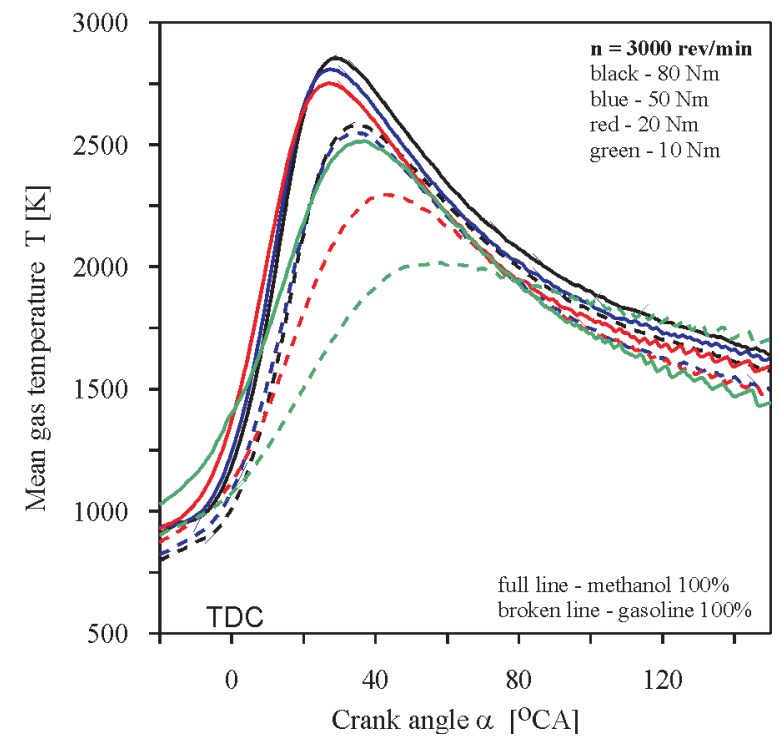

Fig. 5. Comparison of mean charge temperature in function of crank angle for a various engine loads Rys. 5. Porównanie średniej temperatury czynnika w funkcji kąta obrotu wału korbowego dla różnych obciążén silnika

\section{Heat release rate}

In the Figure 6 is shown a comparison of heat release rate in function of crankshaft rotation angle in the interval of the highest dynamics of the combustion $-20 \div+50^{\circ} \mathrm{CA}$. The comparison was made for a various engine loads. From analysis of curves shown in the Fig. 6 is seen that in case of combustion of methanol, much higher heat release rates occur as early as during initial phase of the combustion. In result, maximal values of $(\mathrm{dQ} / \mathrm{d} \alpha)_{\max }$ are higher and occur earlier with respect to gasoline. Such tendency can be noticed for all engine loads and rotational speeds. The highest differences were recorded for low engine loads $(10 \mathrm{~N} \cdot \mathrm{m}, 20$ $\mathrm{N} \cdot \mathrm{m}$ ). Maximal heat release rate for alcohol was in that case nearly twice higher than in case of gasoline, and heat release process alone shows at significant growth of combustion dynamics at beginning of the process (tangent to the heat release rate curve of methanol is steeper than the tangent for porównywalne temperatury do uzyskiwanych przy spalaniu benzyny i wysokich obciążeniach silnika (linie przerywane kolor niebieski i czarny).

\section{Szybkość wydzielania ciepła}

$\mathrm{Na}$ rysunku 6 przedstawiono porównanie szybkości wydzielania ciepła w zależności od kąta obrotu wału korbowego w przedziale największej dynamiki spalania -20 do $+50^{\circ} \mathrm{OWK}$. Porównania dokonano dla różnych obciążeń silnika. $Z$ analizy krzywych pokazanych na rys. 6 wynika, że przy spalaniu metanolu występują znacznie większe szybkości wydzielania ciepła już w początkowej fazie spalania. $\mathrm{W}$ efekcie maksymalne wartości $(\mathrm{dQ} / \mathrm{d} \alpha)_{\max }$ są większe i występują wcześniej w stosunku do benzyny. Tendencja ta zauważalna była dla wszystkich obciążeń i prędkości obrotowych. Największe różnice odnotowano dla małych obciążeń silnika $(10 \mathrm{~N} \cdot \mathrm{m}, 20 \mathrm{~N} \cdot \mathrm{m})$. Maksymalna szybkość wydzielania ciepła dla alkoholu była wtedy prawie dwa razy 
gasoline). It is also characteristic fact that for higher engine loads differences in inclination of the tangents for methanol and gasoline are diminishing. Transient differences in heat release rate for the methanol are higher with $20-80 \%$, comparing to gasoline.

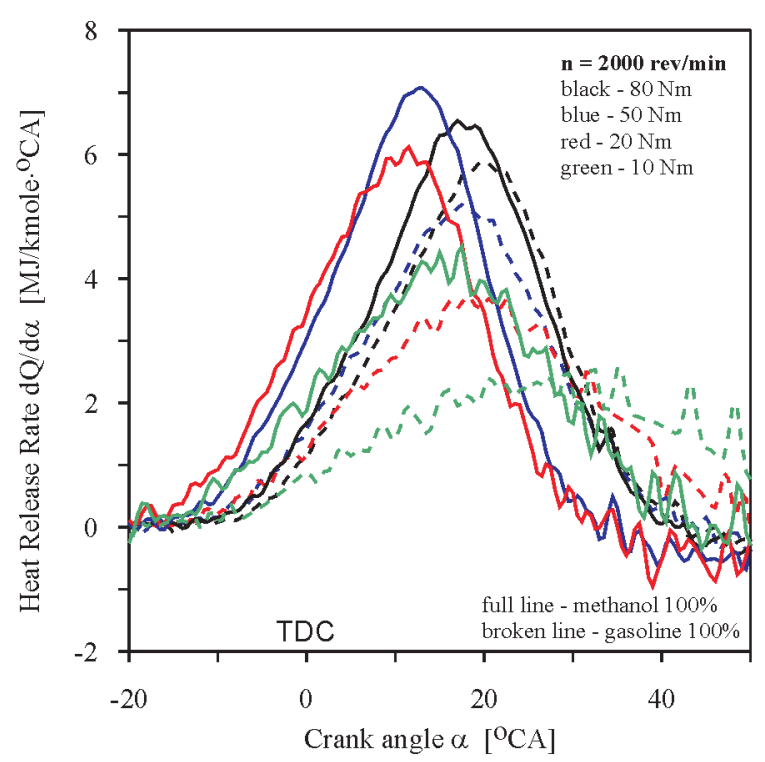

większa niż dla benzyny, a sam proces wydzielania ciepła wykazuje znaczny wzrost dynamiki spalania na początku procesu (styczna do krzywej szybkości wydzielania ciepła dla metanolu jest bardziej stroma od stycznej dla benzyny). Charakterystyczne jest również to, że dla większych

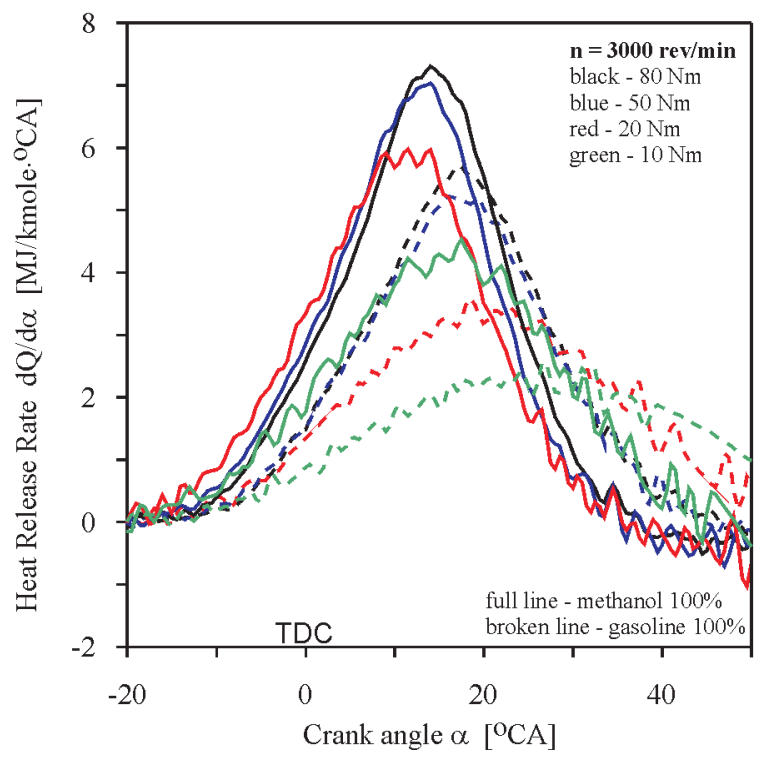

Fig. 6. Comparison of heat release rate in function crank angle for a various engine loads Rys. 6. Porównanie szybkości wydzielania ciepła w funkcji kąta obrotu wału korbowego dla różnych obciążeń silnika

\section{Rate of Pressure Rise}

Comparison of pressure growth rate in the cylinder as function of crank angle rotation is illustrated in the Fig 7. From presented characteristics is seen that process of combustion of alcohol is accompanied by more rapid and higher pressure growth, and more violent pressure drop. Such tendency is seen for the whole range of engine loads. It can be also noticed, that for the same engine parameters, both in case of gasoline and methanol, the highest pressure growth obciążeń różnice w nachyleniu stycznych dla metanolu i benzyny zmniejszają się. Chwilowe różnice w szybkości wydzielania ciepła są dla metanolu większe o $20-80 \%$ w stosunku do benzyny.

Szybkość przyrostu ciśnienia

Porównanie szybkości przyrostu ciśnienia w cylindrze w zależności od kąta obrotu wału korbowego przedstawia rys. 7. $\mathrm{Z}$ przedstawionych charakterystyk wynika, że procesowi spalania alkoholu towarzyszy szybszy i większy wzrost
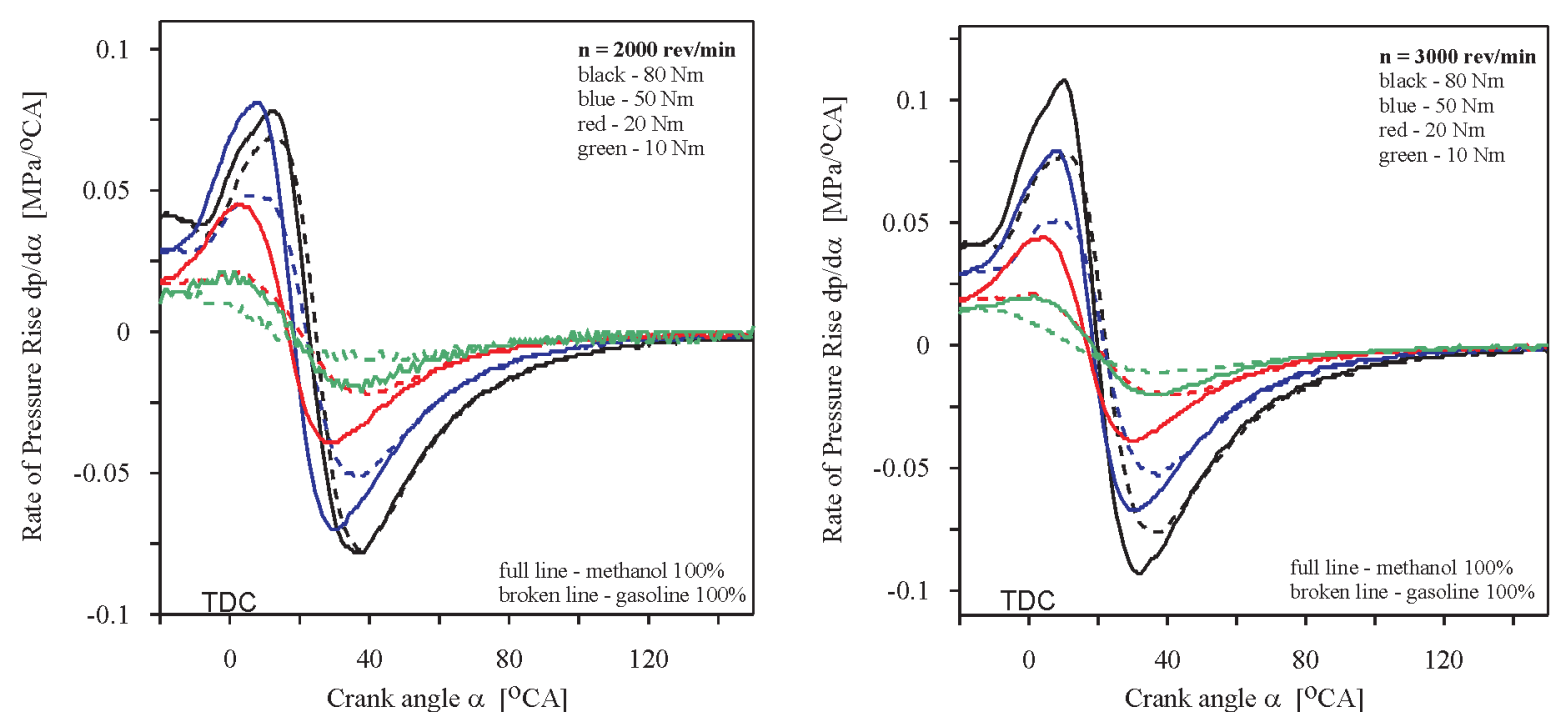

Fig. 7. Comparison of rate of pressure rise in function crank angle for a various engine loads

Rys. 7. Porównanie szybkości przyrostu ciśnienia w funkcji kąta obrotu wału korbowego dla różnych obciążén silnika 
rates are present at the same crank rotation angles. In case of pressure drops, combustion of methanol is accompanied by obtained in shorter time minimum with respect to gasoline, what can prove more quick advancement of combustion process of alcohol. For low engine loads $(10 \mathrm{~N} \cdot \mathrm{m}, 20 \mathrm{~N} \cdot \mathrm{m})$ it is also interesting that, when pressure growth for gasoline is of more static character, methanol exhibits slight but noticeable growth as early as for $10 \mathrm{~N} \cdot \mathrm{m}$, and for $20 \mathrm{~N} \cdot \mathrm{m}$ pressure growth rate is already strongly dynamic (value compared to load of $40 \mathrm{~N} \cdot \mathrm{m}$ for gasoline). Character of pressure growth, $\mathrm{dp} / \mathrm{d} \alpha$, for gasoline testifies for protracted combustion of gasoline at minimal engine loads. Seems that it can result from increased reaction of residues of exhaust gases, growth of natural EGR connected with throttling of the air. Effect of exhaust gases on air-methanol mixture is significantly lower.

Comparison of maximal values of a selected combustion parameters in function of engine load is shown in the Figs. 8-14. Except the parameters discussed earlier, there were additionally analyzed indicated efficiency, $\eta_{i}$, and total combustion angle, $\alpha_{\text {comb }}$. Combustion angle was calculated as difference between termination of combustion, at which polytrophic exponent is equal to adiabatic exponent $\mathrm{m}=$ $\kappa$, and beginning of combustion. Both parameters $\mathrm{m}$ and $\kappa$ were calculated numerically with calculation step in course of combustion process analysis, taking into consideration actual composition of the gas inside the cylinder.

In the Figure 8 are shown differences of indicated efficiency developed by the engine run on gasoline and methanol. From analysis of the diagram is seen that during combustion of methanol a higher indicated efficiencies are developed comparing to combustion of gasoline. Such feature is present both in whole range of engine loads and for all engine speeds (in the interval of $10-20 \%$ of the maximal load) and amounts to about 5-6\%, whereas for a bigger loads the differences amount to $3-4 \%$ in favour of methyl alcohol. Characteristics of indicated efficiency of the engine for methanol and gasoline are similar, and for the both fuels character of efficiency growth is nearly identical.
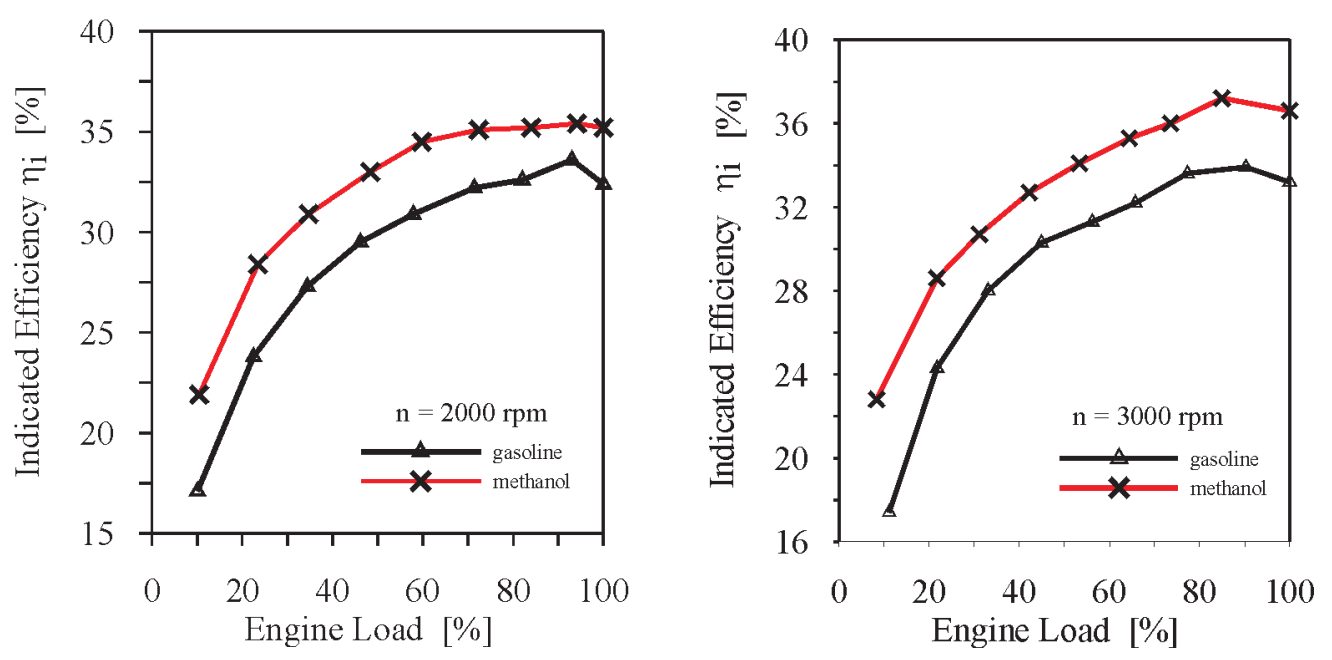

Fig. 8. Comparison of indicated efficiency the dual fuelled engine in function of engine load Rys. 8. Porównanie sprawności indykowanej silnika dwupaliwowego jako funkcji obciążnia silnika ciśnienia oraz gwałtowniejszy jego spadek. Ta tendencja jest widoczna dla całego zakresu obciążeń silnika. Można również zauważyć, że dla tych samych parametrów silnika, zarówno dla benzyny, jak i metanolu największe szybkości przyrostu ciśnienia występują przy tych samych kątach obrotu wału korbowego. W przypadku spadków ciśnień, spalaniu metanolu towarzyszy szybsze osiąganie minimum w stosunku do benzyny, co świadczy o szybszym postępie procesu spalania alkoholu. Dla małych obciążeń silnika (10 $\mathrm{N} \cdot \mathrm{m}, 20 \mathrm{~N} \cdot \mathrm{m}$ ) interesujący jest również fakt, że o ile przyrost ciśnienia dla benzyny ma charakter bardziej statyczny, to metanol już dla $10 \mathrm{~N} \cdot \mathrm{m}$ wykazuje niewielki, ale zauważalny wzrost, a dla $20 \mathrm{~N} \cdot \mathrm{m}$ szybkość przyrostu ciśnienia jest już bardzo dynamiczna (wielkością porównywalna $\mathrm{z}$ obciążeniem $40 \mathrm{~N} \cdot \mathrm{m}$ dla benzyny). Charakter przyrostu ciśnienia dp/d $\alpha$ dla benzyny świadczy o przewlekłym spalaniu benzyny przy minimalnych obciążeniach silnika. Wydaje się, że może to wynikać ze zwiększonego oddziaływania pozostałości spalin, wzrostu naturalnego EGR, związanego z dławieniem powietrza. Oddziaływanie spalin na mieszaninę powietrze-metanol jest mniejsze.

Porównanie maksymalnych wartości wybranych parametrów spalania w funkcji obciążenia silnika przedstawiono na rys. 8-14. Oprócz omawianych wcześniej parametrów analizie poddano dodatkowo sprawność indykowaną $\eta_{i}$ oraz całkowity kąt spalania $\alpha_{\text {comb }}$. Kąt spalania wyznaczono jako różnicę między końcem spalania, przy którym wykładnik politropy jest równy wykładnikowi adiabaty $\mathrm{m}=\kappa$, a początkiem spalania. Obydwa parametry $\mathrm{m}$ i $\kappa$ obliczano numerycznie, w kroku obliczeniowym w trakcie analizy procesu spalania, uwzględniając aktualny skład gazów w cylindrze.

Na rysunku 8 przedstawiono różnice w sprawności indykowanej silnika zasilanego benzyną i metanolem. Z analizy rysunku wynika, że przy spalaniu metanolu uzyskano większe sprawności indykowane niż przy spalaniu benzyny. Prawidłowość ta występuje zarówno w całym zakresie obciążeń, jak i dla wszystkich prędkości obrotowych silnika. Największe różnice bezwzględne można zaobserwować dla mniejszych obciążeń silnika (w przedziale 10-20\% maksymalnego obciążenia) i wynoszą one około $5-6 \%$, a dla większych obciążeń różnice te wynoszą 3-4\% na korzyść alkoholu metylowego. Charakterystyki sprawności indykowanych silnika dla metanolu jak i dla benzyny są podobne, i dla obu paliw charakter wzrostu sprawności jest niemal identyczny.

Większe szybkości spalania alkoholu powodują zwiększenie wartości ciśnień mak- 
Higher rates of alcohol combustion effect in growth of maximal pressure values, $\mathrm{p}_{\max }$, with respect to the pressures occurring during feeding with gasoline (Fig. 9). Character of maximal pressure change in function of load for gasoline and alcohol is similar (especially for $3000 \mathrm{rpm}$ ). Together with growth of engine load, maximal pressure in the cylinder increases monotonically. However, for the same engine load when the engine runs on gasoline, pressures in the cylinder are higher with $0,4-0,5$ $\mathrm{MPa}$. It seems, that growth of maximal pressure not exceeding $10 \%$ of recorded pressures for gasoline fuelling should not effect on durability of the engine which is run on alcohol only.

Dependence of maximal pressure rates, $(\mathrm{d} / \mathrm{d} \alpha)_{\max }$, on engine load is presented in the Fig. 10. Making comparison of the characteristics for the both engine speeds it can be noticed, that in result of combustion of methanol, maximal pressure growth rates are higher than in case of gasoline fuelling. Only for the lowest loads (order of
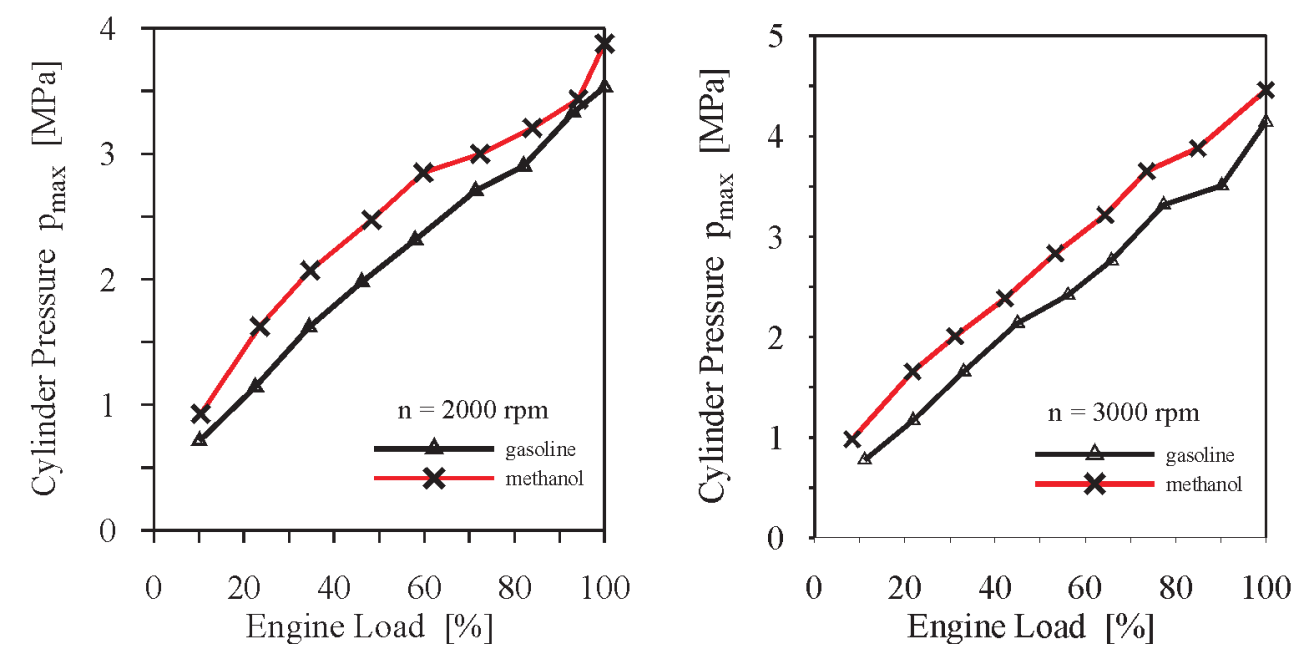

Fig. 9. Comparison of maximal cylinder pressure the dual fuelled engine in function of engine load Rys. 9. Porównanie maksymalnego ciśnienia $w$ cylindrze jako funkcji obciążenia silnika dwupaliwowego symalnych $\mathrm{p}_{\max }$ w stosunku do występujących dla zasilania benzyną (rys. 9). Porównanie charakterystyk ciśnień wskazuje, że ciśnienia maksymalne dla alkoholu są większe o zbliżoną wartość około $0,4-0,5 \mathrm{MPa}$, co powoduje, że charakter zmian w funkcji obciążenia jest prawie identyczny (zwłaszcza dla 3000 obr/min). Wydaje się, że wzrost ciśnienia maksymalnego nieprzekraczający $10 \%$ ciśnień rejestrowanych dla zasilania benzyną, nie powinien wpływać na trwałość silnika zasilanego samym alkoholem.
$10 \%$ of the maximal load)

values of $(\mathrm{dp} / \mathrm{d} \alpha)_{\max }$ are comparable for the both fuels. The biggest differences can be observed in range of medium engine loads (order of 30-70\%), where maximal rates of pressure growth for engine speed of $2000 \mathrm{rpm}$ are nearly two times higher, whereas for $3000 \mathrm{rpm}$ are in average $30 \%$ higher than for gasoline. Higher pressure growth rates, $(\mathrm{dp} / \mathrm{d} \alpha)_{\max }$, effect in a slight growth of noisiness of combustion process. It should not have, however, any significant effect on overall noisiness of the engine, because noise from the combustion constitutes only one from many, and

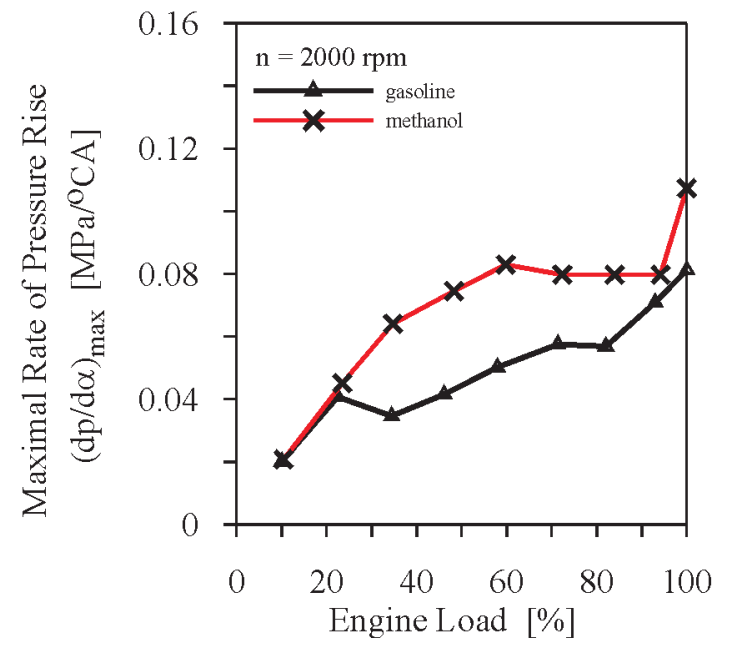

Zależność maksymalnych szybkości ciśnienia $(\mathrm{dp} / \mathrm{d} \alpha)_{\max }$ od obciążenia silnika przedstawia rys. 10. Porównując charakterystyki dla obu prędkości obrotowych, możemy zauważyć, że w wyniku spalania metanolu maksymalne szybkości przyrostu ciśnienia są większe niż przy spalaniu benzyny. Tylko dla najmniejszych obciążeń (rzędu 10\% obciążenia maksymalnego) wartości $(\mathrm{dp} / \mathrm{d} \alpha)_{\max }$ są porównywalne dla obu paliw. Największe różnice można zaobserwować w zakresie średnich obciążeń silnika (rzędu 30-70\%), gdzie maksymalne szybkości przyrostu ciśnienia dla prędkości

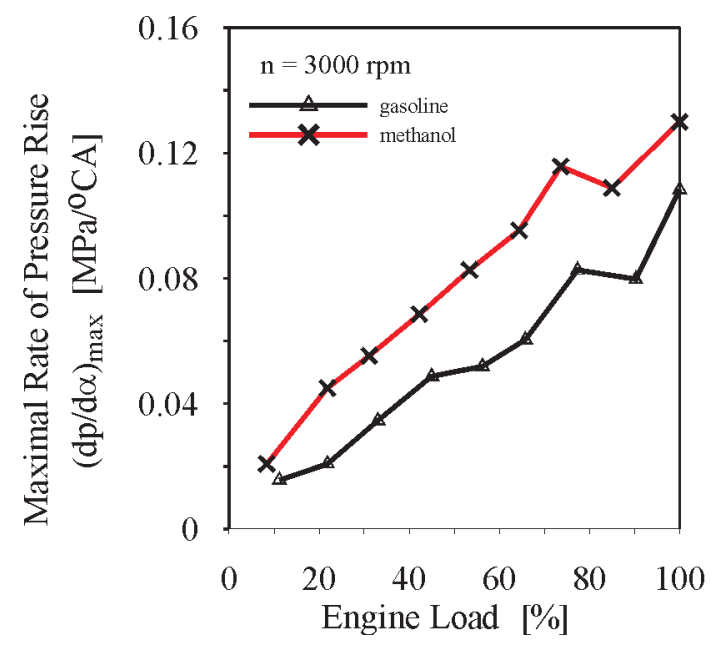

Fig. 10. Comparison of maximal rate of pressure rate the dual fuelled engine in function of engine load Rys. 10. Porównanie maksymalnej szybkości przyrostu ciśnienia jako funkcji obciążenia silnika dwupaliwowego 
in case of spark ignition engine not the highest, component of general noisiness of the engine.

Comparison of values of maximal heat release rates, $(\mathrm{dQ} / \mathrm{d} \alpha)_{\max }$, for the both fuels confirms a higher dynamics of energetic expenditure during combustion of the methanol. It proves that during combustion of alcohol, maximal heat obrotowej 2000 obr/min są prawie dwa razy większe, a dla $3000 \mathrm{obr} / \mathrm{min}$ średnio o 30\% większe niż dla benzyny. Większe szybkości narastania ciśnienia $(\mathrm{dp} / \mathrm{d} \alpha)_{\max }$ powodują nieznaczny wzrost hałaśliwości procesu spalania. Nie powinno to jednak mieć istotnego wpływu na hałaśliwość ogólną silnika, bowiem hałas procesu spalania jest tylko jednym, a w

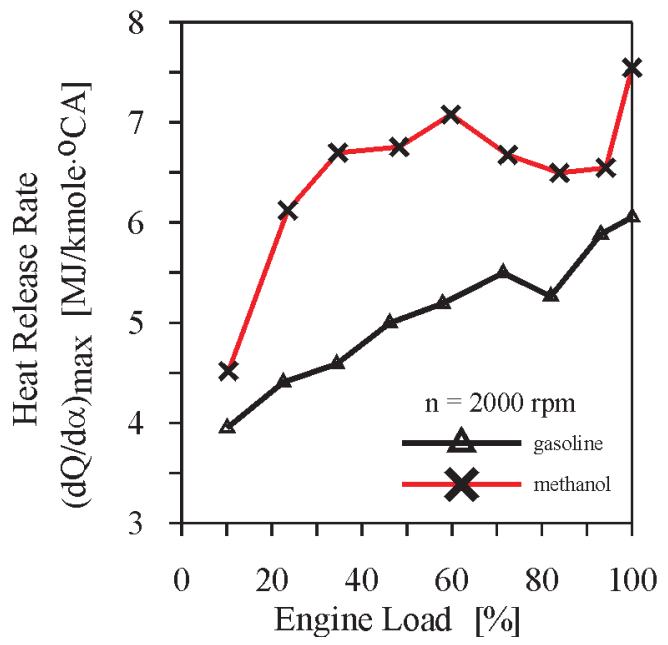

przypadku silnika o zapłonie iskrowym nie największym, składnikiem hałaśliwości ogólnej silnika.

Porównanie wartości maksymalnych szybkości wydzielania ciepła $(\mathrm{dQ} /$ $\mathrm{d} \alpha)_{\max }$ dla obu paliw potwierdza większą dynamikę wydatku energetycznego podczas spalania metanolu. Okazuje się, że podczas spalania alkoholu maksymalne szybkości wydzieleń ciepła są

release rates are significantly higher than in case of gasoline and it concerns all spectrum of engine loads and all engine speeds. Differences in heat release rates amount to $50-80 \%$ with respect to recorded ones during fuelling with gasoline.

Maximal temperatures of the working medium during combustion of methanol are significantly higher comparing to combustion of methanol (Fig. 12). From analysis of the curves is seen that the highest differences occur for low engine loads. For engine speed of $2000 \mathrm{rpm}$ the difference amounted to about $430^{\circ} \mathrm{C}$, whereas in case of $3000 \mathrm{rpm}$ to nearly $450^{\circ} \mathrm{C}$. Together with growth of engine load these differences decrease to about $200-250^{\circ} \mathrm{C}$. It is worth to be noticed that methanol reaches its maximal temperatures as early as at low engine loads (of the order of 20\%), maintaining these temperatures at nearly constant level even during increase of engine load. Growing tendency of maximal temperatures for gasoline shows in that range more soft character.

The Figure 13 presents comparison of total combustion angle for gasoline and methanol. It is character-
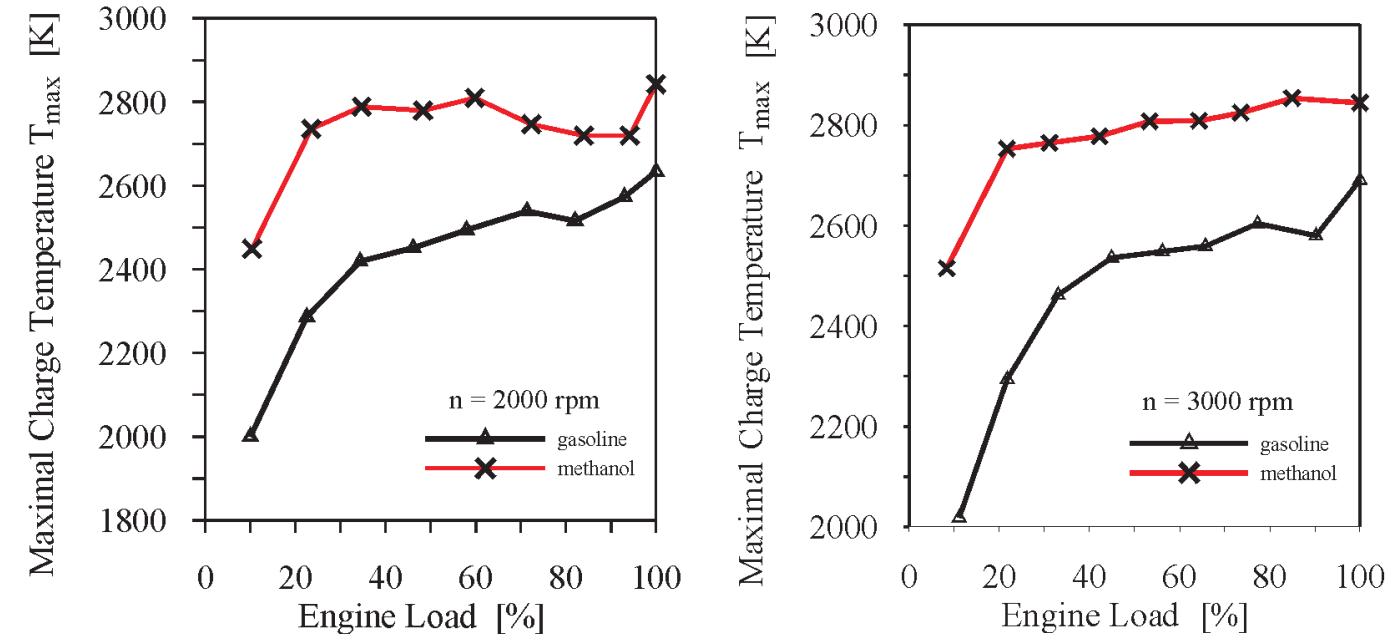

Fig. 12. Comparison of maximal charge temperature of the dual fuelled engine in function of engine load Rys. 12. Porównanie maksymalnej temperatury czynnika jako funkcji obciążenia silnika dwupaliwowego 
istics that for the lowest engine loads, order of $10 \%$, alcohol is burnt in nearly twice shorter time than gasoline. As engine load increases, however, angle of combustion of fuel dose becomes more and more small, approaching in this way to the angles of burning of methanol, but is still bigger with about $10^{\circ} \mathrm{CA}$ than combustion angle of methanol. Only for the highest engine loads one can observe a comparable angles for the both fuels (especially for $3000 \mathrm{rpm}$ ). From analysis poziomie podczas zwiększenia stopnia obciążenia silnika. Tendencja wzrostu temperatur maksymalnych dla benzyny wykazuje w tym zakresie bardziej łagodny charakter.

Na rysunku 13 przedstawiono porównanie całkowitego kąta spalania ładunku dla metanolu i benzyny. Charakterystyczne jest, że dla najmniejszych obciążeń silnika rzędu $10 \%$ alkohol spala się w czasie dwa razy krótszym niż benzyna. W miarę zwiększania obciążenia silnika kąt spalania

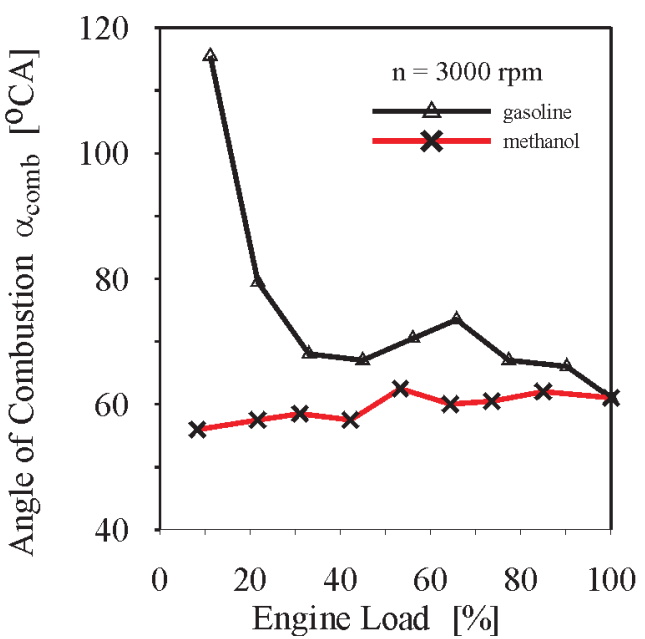

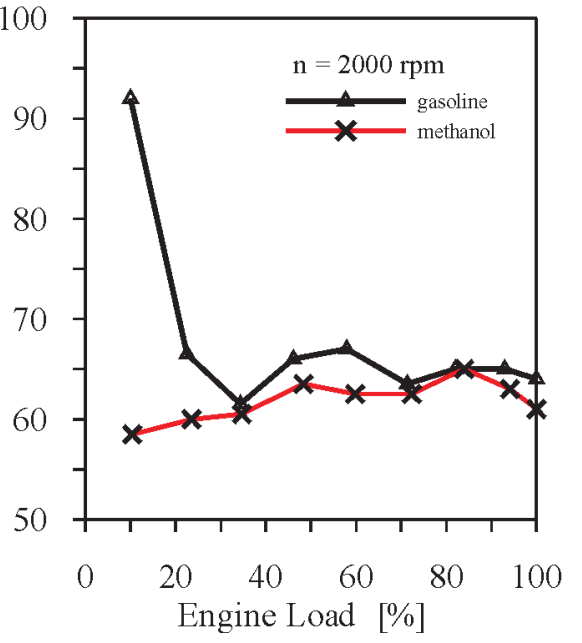

Engine Load $[\%]$ dawki benzyny jest jednak coraz mniejszy, zbliżając się $\mathrm{w}$ ten sposób do kątów osiąganych przez metanol, ale w dalszym ciągu jest o około $10^{\circ}$ OWK większy od kąta spalania dla metanolu. Jedynie dla największych obciążeń można zaobserwować porównywalne kąty dla obydwu paliw (zwłaszcza dla 3000 obr/min). Z analizy krzywych wynika, że zmiany całkowitego kąta spalania alkoholu metylowego wraz ze

of the curves is seen that changes of total combustion angle of methyl alcohol together with change of engine load are small (for $2000 \mathrm{rpm}, \alpha_{\text {comb }}$ changes in range of 58-64 $\mathrm{CA}$; and for $3000 \mathrm{rpm}, \alpha_{\text {comb }}$ changes in range of 56-62 $\mathrm{CA}$ ). From analysis of the curves shown in the Fig. 13 is seen that combustion of gasoline at low engine loads (high degree of air throttling) is very protracted what effects in a considerable prolongation of the total combustion angle.

\section{Conclusions}

The paper presents differences between selected parameters of combustion process of gasoline and methanol in the engine adapted to dual fuel operation. Making comparison of combustion run of the both fuels one can conclude that combustion of methanol is accompanied by:

- higher pressures in the cylinder and higher rates of pressure growth, comparing to gasoline

- higher thermal loads of the engine, what can be proved by considerably higher average temperatures and maximal temperatures in the cylinder

- higher maximal heat release rates, what causes that methanol is a fuel more active energetically in the whole process of combustion

- higher indicating efficiencies comparing to gasoline

- higher average combustion rates what can be confirmed by smaller angles of total combustion of the charge

- methanol is the fuel, which as early as for the lowest engine loads is characteristic of considerable higher dynamics of combustion process comparing to gasoline. Owing to it, in range of low engine loads there were recorded a highest zmianą obciążenia silnika są niewielkie (dla 2000 obr/min $\alpha_{\text {comb }}$ zmienia się w zakresie $58-64^{\circ} \mathrm{OWK}$, a dla 3000 obr/ min w zakresie 56-62 $\left.{ }^{\circ} \mathrm{OWK}\right)$. Z analizy krzywych pokazanych na rys. 13 wynika, że spalanie benzyny przy małych obciążeniach silnika (wysoki stopień dławienia powietrza) jest bardzo przewlekłe, co powoduje znaczne wydłużenie całkowitego kąta spalania.

\section{Wnioski}

W artykule zaprezentowano różnice pomiędzy wybranymi parametrami procesu spalania benzyny i metanolu w silniku przystosowanym do pracy w systemie dwupaliwowym. Porównując przebieg spalania obydwu paliw, można wnioskować, że spalaniu metanolu towarzyszą:

- większe ciśnienia w cylindrze oraz większe szybkości przyrostu ciśnień w stosunku do benzyny

- większe obciążenia cieplne silnika, czego dowodem są znacznie większe średnie temperatury oraz temperatury maksymalne panujące w cylindrze

- większe maksymalne szybkości wydzielania ciepła, co sprawia, że metanol jest paliwem bardziej aktywnym energetycznie od benzyny w całym procesie spalani

- większe sprawności indykowane niż dla benzyny

- większe średnie szybkości spalania, co potwierdzają mniejsze kąty całkowitego spalania ładunku

- metanol jest paliwem, który już dla najmniejszych obciążeń silnika charakteryzuje się znacznie większą dynamiką procesu spalania w stosunku do benzyny. Dzięki temu w zakresie małych obciążeń odnotowano największe różnice pomiędzy parametrami spalania benzyny i metanolu. 
differences between combustion parameters of gasoline and methanol.

The above conclusions were observed for all engine speeds and for all spectrum of engine loads.

The research described in the present paper was accomplished within framework of research grant No. PB 4543/B/T02/2007/33 financed by Polish Ministry of Science and Education.
Powyższe wnioski zaobserwowano dla wszystkich prędkości obrotowych oraz dla całego zakresu obciążeń silnika.

Badania opisywane w niniejszej pracy wykonano $\mathrm{w}$ ramach grantu badawczego nr PB 4543/B/T02/2007/33 finansowanego przez Ministerstwo Nauki i Szkolnictwa Wyższego.

Artykut recenzowany

\section{Bibligraphy/Literatura}

[1] Stelmasiak Z., Larisch J., Semikow J.: Badania wstępne dwupaliwowego silnika o zapłonie iskrowym zasilanego alkoholem metylowym i benzyną, Silniki Spalinowe nr 3/2008.

[2] Merkisz J., Pielecha I.: Alternatywne napędy pojazdów, Wyd. Politechniki Poznańskiej, Poznań 2006.

[3] Baczewski K., Kołdoński T.: Paliwa do silników o zapłonie iskrowym, WKiŁ, Warszawa 2005.

[4] Kowalewicz A.: Metanol jako paliwo do silników spalinowych, Silniki Spalinowe nr 3-4, 1992.

[5] Sitnik L.: Ekopaliwa silnikowe, Oficyna Wydawnicza Politechniki Wrocławskiej, Wrocław 2004.

[6] Jakubowski J.: Silniki samochodowe zasilane paliwami zastępczymi, WKit, Warszawa 1987.

[7] Lotko W.: Studium zastosowań paliw alternatywnych w silnikach o zapłonie samoczynnym, Wyd. Politechniki Radomskiej, Radom 1999.

[8] Stelmasiak Z.: Studium procesu spalania gazu w dwupaliwowym silniku o zapłonie samoczynnym zasilanym gazem ziemnym i olejem napędowym, Wydawnictwo Akademii Techniczno-Humanistycznej w Bielsku-Białej, Rozprawy Naukowe nr 5/2003.

[9] www.pan-ol.lublin.pl/wydawnictwa/Motrol5/Szlachta.pdf.

[10] www.ciop.pl/10060, 2003.

[11] www.greencarcongress.com/2008/08/alcohol-boostin.html, 2008.

[12] Maćkowski J.: Emisja aldehydów z silników o ZI zasilanych paliwami zawierającymi związki tlenowe, część 6, Paliwa, oleje i smary w eksploatacji, nr 93; 2001.

[13] Huang Z., Lu H., Jiang D., Zeng K., Liu B., Zhang J., Wang X.: Performance and emissions of a compression ignition engine fueled with diesel/oxygenate blends for various fuel delivery advance angles, Energy \& Fuels 19, 2005, pp. 403-410.

[14] Huang Z., Lu H., Jiang D., Zeng K., Liu B., Zhang J., Wang X.: Combustion behaviors of a compression-ignition engine fuelled with diesel/methanol blends under various fuel delivery advance angles, Bioresource Technology 95, 2004, pp. 331-341.

[15] Wu C-W., Chen R-H., Pu J-Y., Lin T-H.: The influence of airfuel ratio on engine performance and pollutant emission of an SI engines using ethanol-gasoline-blended fuels, Atmospheric Environment 38, 2004, pp. 7093-7100.

[16] Al-Hasan M.: Effect of ethanol-unleaded gasoline blends on engine performance and exhaust emission, Energy Conversion and Management 44, 2003, pp. 1547-1561.

[17] Li D., Zhen H., Xingcai L., Wu-gao Z., Jian-guang Y.: Physicochemical properties of ethanol-diesel blend fuel and its effect

Mr. Jerzy Larisch, DEng. - doctor in the Departament of Internal Combustion Engines and Vehicles at Technical University of Bielsko-Biała.

Dr inż. Jerzy Larisch - adiunkt w Katedrze Silników Spalinowych i Pojazdów Akademii TechnicznoHumanistycznej w Bielsku-Białej.

e-mail: jlarisch@ath.bielsko.pl on performance and emissions of diesel engines, Renewable Energy 30, 2005, pp. 967-976.

[18] Can Ö., Çelikten I., Usta N.: Effects of etanol addition on performance and emissions of a turbocharged indirect injection diesel engine running at different injection pressures, Energy Conversion and Management 45, 2004, pp. 2429-2440.

[19] He B-Q., Shuai S-J., Wang J-X., He H.: The effect of ethanol blended diesel fuels on emissions from a diesel engine, Atmospheric Environment 37, 2003, pp. 4965-4971.

[20] Hsieh W-D., Chen R-H., Wu T-L., Lin T-H.: Engine performance and pollutant emission of an SI engine using ethanol-gasoline blended fuels, Atmospheric Environment 36, 2002, pp. 403-410.

[21] Bayraktar H.: Theoretical investigation of flame propagation process in an SI engine running on gasoline-ethanol blends, Renewable Energy 32, 2007, pp. 758-771.

[22] Xing-cai L., Jian-guang Y., Wu-gao Z., Zhen H.: Effect of cetane number improver on heat release rate and emissions of high speed diesel engine fueled with ethanol-diesel blend fuel, Fuel 83, 2004, pp. 2013-2020.

[23] He B-Q., Wang J-X., Hao J-M., Yan X-G., Xiao J-H.: A study on emission characteristics of an EFI engine with ethanol blended gasoline fuels, Atmospheric Environment 37, 2003, pp. 949-957.

[24] Ajav A.E., Singh B., Bhattacharya T.K.: Experimental study of some performance parameters of a constant speed stationary diesel engine using ethanol-diesel blends as fuel, Biomass and Bioenergy 17, 1999, pp. 357-365.

[25] Chen H., Shuai S-J., Wang J-X.: Study on combustion characteristics and PM emission of diesel engines using esterethanol-diesel blended fuels, Proceedings of the Combustion Institute 31, 2007, pp. 2981-2988.

[26] Qi D-H., Liu Sh-Q., Liu J-C., Zhang Ch-H., Bian Y-Zh.: Properties, performance, and emissions of methanol-gasoline blends in a spark ignition engine, Automobile Engineering Vol. 219 Part D, 2004.

[27] Kára J.: Biofuels with content of bioethanol for diesel engines, Institut of Agricultural Engineering, Praha 2005.

Mr. Zdzisław Stelmasiak, DSc, DEng. - Professor in the Faculty of Mechanical Engineering and Computer Sciences at Technical University of Bielsko-Biała. Dr hab. inż. Zdzisław Stelmasiak - profesor na Wydziale Budowy Maszyn i Informatyki Akademii Techniczno-Humanistycznej w Bielsku-Białej. e-mail:zstelmasiak@ath.bielsko.pl

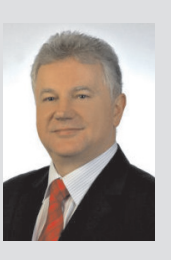

Mr. Janusz Semikow, MEng. - postgraduate in the Departament of Internal Combustion Engines and Vehicles at Technical University of Bielsko-Biała.

Mgr inż. Janusz Semikow - doktorant w Katedrze Silników Spalinowych i Pojazdów Akademii TechnicznoHumanistycznej w Bielsku-Białej.

e-mail:jsemikow@poczta.onet.pl 